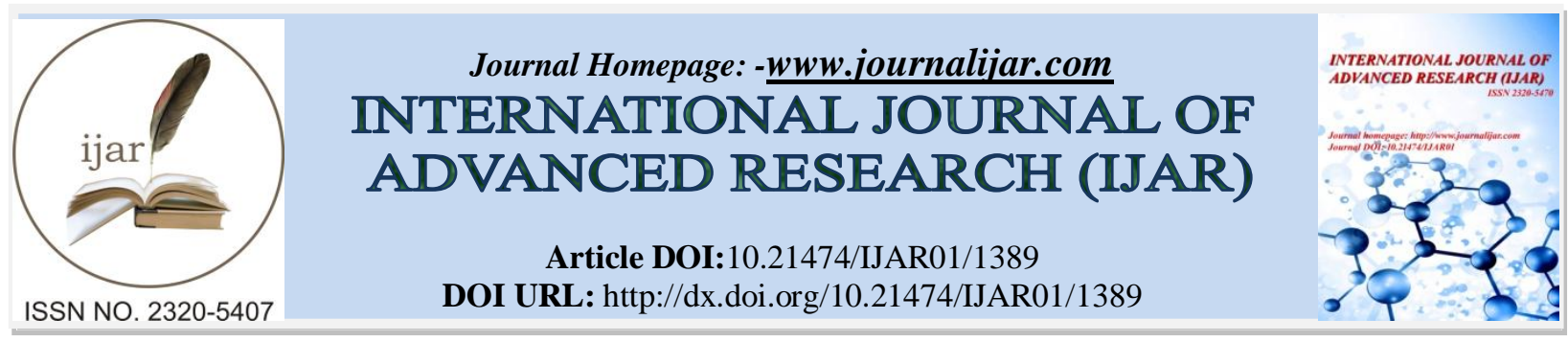

RESEARCH ARTICLE

\title{
A PRELIMINARY STUDY ON THE SUCCESSION OF INSECT VISITORS AND THEIR SYMBIOTIC INTERACTION FOR EFFECTIVE POLLINATION IN BRASSICA JUNCEA (L.) OF SOUTHERN WEST BENGAL.
}

Souradip Roy ${ }^{1}$, Subhrajit Bhaumik ${ }^{1}$, Imtiaz Imam $^{2}$, Tania Chatterjee ${ }^{1}$, Kuladeep Roy ${ }^{3}$ and Bulganin Mitra ${ }^{4}$

1. Post Graduate Department of Zoology, Vidyasagar College, Sector -2, CL Block, Salt Lake City, Kolkata 700091, India.

2. Zoological Survey of India, North Eastern Regional Centre, Risa Colony, Shillong-793003, India.

3. Assistant manager WWF, India, West Bengal State Office, Tata centre 1st floor, Jawaharlal Nehru road, Kolkata- 700071, India.

4. Scientist - C, Zoological Survey of India, Kolkata - 700053, India.

\section{Manuscript Info}

Manuscript History

Received: 19 June 2016

Final Accepted: 12 July 2016

Published: August 2016

Key words:-

Brassica juncea L., insect visitors, inventory, West Bengal.

\section{Abstract}

A preliminary study was conducted for nine days in a commercial crop field at Haripal in Hooghly district of West Bengal during the flowering phase of Brassica juncea L. to observe the periodical occurrence of various insect visitors and their role in pollination. 29 insect species belonging to 16 families under 7 orders were recorded as visitors of Brassica. As a whole, Lepidoptera had maximum number of species occurrence followed by Coleoptera and Hymenoptera. It has also been observed that species were found to visit in different parts of plant but most of them had a common location with flowers. It is indicated that most of the insect species has specific intension of nectar collection which led the pollination efficiency. Symbiotic interaction of the visited insect species was also studied.

Copy Right, IJAR, 2016,. All rights reserved.

\section{Introduction:-}

Survey of insect pollinators in any cultivation field is a common field work practice to get an idea of abundance of pollinator species or visitors (Mitra, 2010; Mitra et al., 2005). The blooming phase of any plant is the most crucial period as the diversity of insects, both occasional and regular is higher than any other phase of that plant species (Bhalchandra et al., 2014; Rasheed et al. 2015; Ali et al., 2015; Nicholls and Altieri, 2012; Belavadi and Ganeshaiah, 2013). However, there are many species which perform their activities only as visitor of flowers or sometimes remain as local inhabitants only. So, overall survey and inventory of insect species at the blooming phase of nectar plants keep records of taxa, their availability and abundance.

However, the major aims of the present study was to record the insect diversity and their visitation pattern, visited plant parts, presence and absence during the flowering period, abundance, and moreover their biological role on Brassica juncea L. According to Atmowidi et al. (2007) and Kunjwal et al. (2014), the location of the collected specimens on plant individuals, like flower, leaf, stem etc. and also their pollination status like effective pollinators, visitors etc. can give an idea of plant-insect interaction of Brassica sp. There are earlier studies also which revealed

Corresponding Author:-Subhrajit Bhaumik.

Address:- Post Graduate Department of Zoology, Vidyasagar College, Sector -2, CL Block, Salt Lake 
the insect species abundance of Brassica sp. at the blooming phase (Atmowidi et al., 2007; Goswami and Khan, 2014).

The mutual occurrence of species-pairs is a co-species or con-generic interaction where more than two species assemblage for the same resources (Kulloli et al., 2011; Hu et al. 2005). The presence of a species or any particular taxon may affect the occurrence of another species or some taxon at the same time period (Alagumurugan et al. 2011; Navatha et al., 2012; Duara and Kalita, 2013). The symbiotic interactions between species-pairs among the insect species were also noticed in the present study. But the conclusion in details this type of symbiotic information could not be possible from the present study as the records of mutual occurrences were mostly based on limited observation.

The present study reports 29 insect species belonging to 16 families under 7 orders of insect visitors of Brassica juncea L. Of them, Lepidoptera shares maximum number of species (8 species), followed by Coleoptera (7 species) and Hymenoptera (5 species).

\section{Methods:-}

The study was conducted at Krishnapur, Haripal in Hooghly district of West Bengal $\left(22^{0} 49^{\prime} \mathrm{N}, 88^{0} 6^{\prime}\right.$ E). The insect species on Brassica juncea L. during its blooming phase was recorded from $22^{\text {nd }}$ January to $19^{\text {th }}$ February of 2016. The study site (almost $937.56 \mathrm{~m}^{2}$ ) was a cultivation land of Brassica. The samplings were planted keeping an average distance of $20 \mathrm{~cm} \times 2 \mathrm{~cm}$. The flower visitors were observed for an interval of each 2 minutes within quadrate plots of $1 \mathrm{~m}^{2}$ each. The study was carried out for 9 days of flowering session. The overall observation was recorded by four session, viz., 08:00-10:00 hours (Session 1), 10:00-12:00 hours (Session 2), 12-14 hours (Session 3 ) and 14-16 hours (Session 4) of each day (GMT+5:30).

Collection of insects was made by insect sweeping net and hand picking methods. The insect species were collected from the samplings of the study sites and from four different locations of the plant individual. The specimens were identified with the help of the experts of Zoological Survey of India, New Alipore, Kolkata.

\section{Result:-}

Of the collected insect species, Delias eucharis (Drury, 1773), Pseudozizeeria maha (Kollar 1848) and Eurema hecabe (Linnaeus, 1758) were found exclusively on flowers. It was also noticed that Lipaphis erysimi Kaltenbach, 1843 and Modicogryllus sp. were found to visit different parts of Brassica other than flowers. One species, Modicogryllus sp. was found to visit only close to root of the plant species. No species were found to visit only stems or leaves of any individual plant. Among the 29 species reported as visitors of Brassica juncea L., the maximum number of species were found from flower (27), followed by Leaf (22) and Stem (10) (Table 1).

Table 1:- List of insect species and their locations when observed on Brassica juncea L.

\begin{tabular}{|c|c|c|c|c|c|c|c|}
\hline \multirow[t]{2}{*}{ No. } & \multirow[t]{2}{*}{ Species } & \multirow[t]{2}{*}{ Order } & \multirow[t]{2}{*}{ Family } & \multicolumn{4}{|c|}{ Locations } \\
\hline & & & & Flower & Stem & Leaf & Near root \\
\hline 1 & Danaus genutia (Cramer, 1779) & Lepidoptera & Nymphalidae & $\mathrm{Y}$ & & $\mathrm{Y}$ & \\
\hline 2 & Delias eucharis (Drury, 1773) & Lepidoptera & Pieridae & $\mathrm{Y}$ & & & \\
\hline 3 & Pseudozizeeria maha (Kollar 1848) & Lepidoptera & Lycanidae & $\bar{Y}$ & & & \\
\hline 4 & Junonia almana Linnaeus, 1758 & Lepidoptera & Nymphalidae & $\mathrm{Y}$ & & $\mathrm{Y}$ & \\
\hline 5 & Amata cyssea Stoll, 1782 & Lepidoptera & Erebidae & $\mathrm{Y}$ & & $\mathrm{Y}$ & $\mathrm{Y}$ \\
\hline 6 & Amata passalis (Fabricius, 1781) & Lepidoptera & Erebidae & $\mathrm{Y}$ & & $\mathrm{Y}$ & $\mathrm{Y}$ \\
\hline 7 & Plutella $\mathrm{sp.}$ & Lepidoptera & Plutellidae & $\mathrm{Y}$ & & $\mathrm{Y}$ & \\
\hline 8 & Eurema hecabe (Linnaeus, 1758) & Lepidoptera & Pieridae & $\mathrm{Y}$ & & & \\
\hline 9 & $\begin{array}{l}\text { Apis (Apis) cerena indica Fabricius, } \\
1798\end{array}$ & Hymenoptera & Apidae & $\mathrm{Y}$ & & $\mathrm{Y}$ & $\bar{Y}$ \\
\hline 10 & Xylocopa fenestrate (Fabricius, 1798) & Hymenoptera & Apidae & $\bar{Y}$ & & $\bar{Y}$ & $\bar{Y}$ \\
\hline 11 & Camponotus sp. & Hymenoptera & Formicidae & $\mathrm{Y}$ & & $\mathrm{Y}$ & \\
\hline 12 & Solenopsis sp. & Hymenoptera & Formicidae & $\mathrm{Y}$ & & $\bar{Y}$ & \\
\hline 13 & Tetraponera sp. & Hymenoptera & Formicidae & $\mathrm{Y}$ & $\mathrm{Y}$ & $\mathrm{Y}$ & \\
\hline
\end{tabular}




\begin{tabular}{|c|c|c|c|c|c|c|c|}
\hline 14 & Altica sp. & Coleoptera & Chrysomelidae & $\mathrm{Y}$ & & $\mathrm{Y}$ & \\
\hline 15 & Aulachophora sp. & Coleoptera & Chrysomelidae & $\mathrm{Y}$ & $\mathrm{Y}$ & & \\
\hline 16 & $\begin{array}{l}\text { Coccinella septempunctata (Linnaeus, } \\
1758 \text { ) }\end{array}$ & Coleoptera & Coccinellidae & $\mathrm{Y}$ & & $\mathrm{Y}$ & \\
\hline 17 & Anisolemnia sp. & Coleoptera & Coccinellidae & $\mathrm{Y}$ & $\mathrm{Y}$ & & \\
\hline 18 & Genocethalum sp. & Coleoptera & Tenebrionidae & $\mathrm{Y}$ & $\mathrm{Y}$ & $\mathrm{Y}$ & \\
\hline 19 & Tachys sp. & Coleoptera & Carabidae & $\mathrm{Y}$ & & $\mathrm{Y}$ & \\
\hline 20 & Phyllotreta striolata Fabricius, 1801 & Coleoptera & Carabidae & $\mathrm{Y}$ & & $\mathrm{Y}$ & \\
\hline 21 & Episyrphus balteatus (De Geer, 1776) & Diptera & Syrphidae & $\mathrm{Y}$ & & $\mathrm{Y}$ & $\mathrm{Y}$ \\
\hline 22 & Atherigona sp. & Diptera & Muscidae & $\mathrm{Y}$ & $\mathrm{Y}$ & $\mathrm{Y}$ & \\
\hline 23 & Ischiodon scutellaris (Fabricius, 1805) & Diptera & Syrphidae & $\mathrm{Y}$ & $\mathrm{Y}$ & $\mathrm{Y}$ & \\
\hline 24 & Crocothemis servilia (Drury, 1773) & Odonata & Libellulidae & $\mathrm{Y}$ & $\mathrm{Y}$ & $\mathrm{Y}$ & \\
\hline 25 & Rhyothemis variegate (Linnaeus, 1763) & Odonata & Libellulidae & $\mathrm{Y}$ & & $\mathrm{Y}$ & \\
\hline 26 & Chrysocoris stolli (Wolff, 1801) & Hemiptera & Scutelleridae & $\mathrm{Y}$ & $\mathrm{Y}$ & & $\mathrm{Y}$ \\
\hline 27 & Lipaphis erysimi Kaltenbach, 1843 & Hemiptera & Aphididae & & $\mathrm{Y}$ & $\mathrm{Y}$ & Y \\
\hline 28 & Dysdercus sp. & Hemiptera & Pyrrhocoridae & $\mathrm{Y}$ & $\mathrm{Y}$ & $\mathrm{Y}$ & \\
\hline 29 & Modicogryllus sp. & Orthoptera & Gryllidae & & & & $\overline{\mathrm{Y}}$ \\
\hline
\end{tabular}

From the present investigation ( Fig.1) it was also revealed that, the insect found to visit maximum in both the plant parts i.e., Flower and Leaf (15) followed by Flower and Stem (03), Stem and Leaf (01), whereas 06 species were only found to visit in commonly used location i.e., Flower, Stem and Leaf (Figure 1).

Figure 1:- species (number were used as identity according to the list of table 1) found from different locations (flower, leaf and stem), location-pairs and commonly used location.

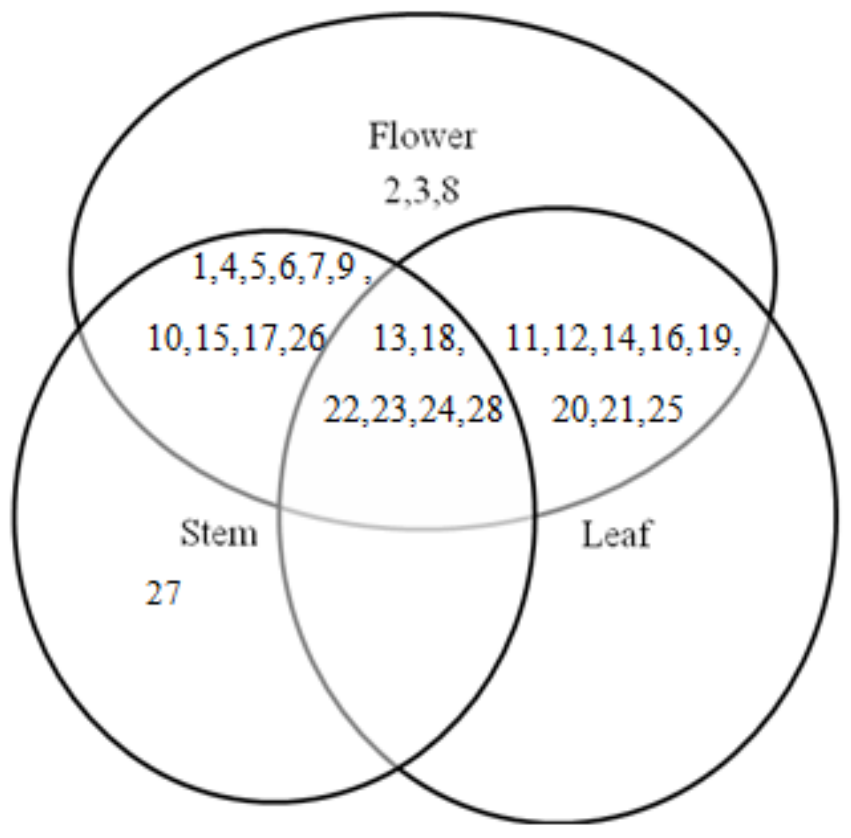

The reported species of the present investigation was categorized as per the previous records and references (Table 2). Out of 29 species reported here, only 5 species, Apis (Apis) cerena indica Fabricius, 1798 (Hymenoptera), Xylocopa fenestrata (Fabricius, 1798) (Hymenoptera), Episyrphus balteatus (De Geer, 1776) (Diptera), Atherigona sp. (Diptera), Ischiodon scutellaris (Fabricius, 1805) (Diptera) were reported as effective pollinators. Apart from these, 10 species, namely, Danaus genutia (Cramer, 1779) (Lepidoptera), Delias eucharis (Drury, 1773) (Lepidoptera), Pseudozizeeria maha (Kollar 1848) (Lepidoptera), Junonia almanac Linnaeus, 1758 (Lepidoptra), Plutella sp. (Lepidoptera), Eurema hecabe (Linnaeus, 1758) (Lepidoptera), Camponotus sp. (Hymenoptera), Solenopsis sp. (Hymenoptera), Tetraponera sp. (Hymenoptera), Anisolemnia sp. (Coleoptera) were recorded as 
pollinators by several authors. Three species, i.e. Amata cyssea Stoll, 1782 (Lepidoptera), Amata passalis (Fabricius, 1781) (Lepidoptera), Coccinella septempunctata (Linnaeus, 1758) (Coleoptera) were recorded as flower visitors. As per the published literature, there is nothing known about the pollination efficiency or as flower visitors of the rest of the species reported during this present investigation.

Table 2:- List of insect species found on Brassica juncea $\mathrm{L}$. in present survey and their role on plant (as per earlier records)

\begin{tabular}{|c|c|c|c|c|c|}
\hline No. & Species & Effective Pollinator & Pollinator & Flower Visitor & Others \\
\hline 1 & Danaus genutia (Cramer, 1779) & & $\mathrm{Y}$ & & \\
\hline 2 & Delias eucharis (Drury, 1773) & & $\mathrm{Y}$ & & \\
\hline 3 & Pseudozizeeria maha (Kollar 1848) & & $\mathrm{Y}$ & & \\
\hline 4 & Junonia almana Linnaeus, 1758 & & $\mathrm{Y}$ & & \\
\hline 5 & Amata cyssea Stoll, 1782 & & & $\mathrm{Y}$ & \\
\hline 6 & Amata passalis (Fabricius, 1781) & & & $\mathrm{Y}$ & \\
\hline 7 & Plutella sp. & & $\mathrm{Y}$ & & \\
\hline 8 & Eurema hecabe (Linnaeus, 1758) & & $\mathrm{Y}$ & & \\
\hline 9 & Apis (Apis) cerena indica Fabricius, 1798 & $\mathrm{Y}$ & & & \\
\hline 10 & Xylocopa fenestrata (Fabricius, 1798) & $\mathrm{Y}$ & & & \\
\hline 11 & Camponotus sp. & & $\mathrm{Y}$ & & \\
\hline 12 & Solenopsis sp. & & $\mathrm{Y}$ & & \\
\hline 13 & Tetraponera sp. & & $\mathrm{Y}$ & & \\
\hline 14 & Altica sp. & & & & $\mathrm{Y}$ \\
\hline 15 & Aulachophora sp. & & & & $\mathrm{Y}$ \\
\hline 16 & Coccinella septempunctata (Linnaeus, 1758) & & & $\mathrm{Y}$ & \\
\hline 17 & Anisolemnia sp. & & $\mathrm{Y}$ & & \\
\hline 18 & Genocethalum sp. & & & & $\mathrm{Y}$ \\
\hline 19 & Tachys sp. & & & & $\mathrm{Y}$ \\
\hline 20 & Phyllotreta striolata Fabricius, 1801 & & & & $\mathrm{Y}$ \\
\hline 21 & Episyrphus sp. & $\mathrm{Y}$ & & & \\
\hline 22 & Atherigona sp. & $\mathrm{Y}$ & & & \\
\hline 23 & Ischiodon scutellaris (Fabricius, 1805) & $\mathrm{Y}$ & & & \\
\hline 24 & Crocothemis servilia (Drury, 1773) & & & & $\mathrm{Y}$ \\
\hline 25 & Rhyothemis variegata (Linnaeus, 1763) & & & & $\mathrm{Y}$ \\
\hline 26 & Chrysocoris stolli (Wolff, 1801) & & & & $\mathrm{Y}$ \\
\hline 27 & Lipaphis erysimi Kaltenbach, 1843 & & & & $\mathrm{Y}$ \\
\hline 28 & Dysdercus sp. & & & & $\mathrm{Y}$ \\
\hline 29 & Modicogryllus sp. & & & & $\mathrm{Y}$ \\
\hline
\end{tabular}

Considering to the availability and abundance of the insect groups visited Brassica, the number of species of order Coleoptera was found to be higher from session 1 to session 2, and lesser in session 3 and session 4 accordingly, lepidopteran species were found in higher abundance from session 1 to session 4 . The number of the recorded species of order Diptera was found to be increased gradually throughout the study period (Figure 2). 
Figure 2:- Abundance of different orders of recorded species in different sessions.

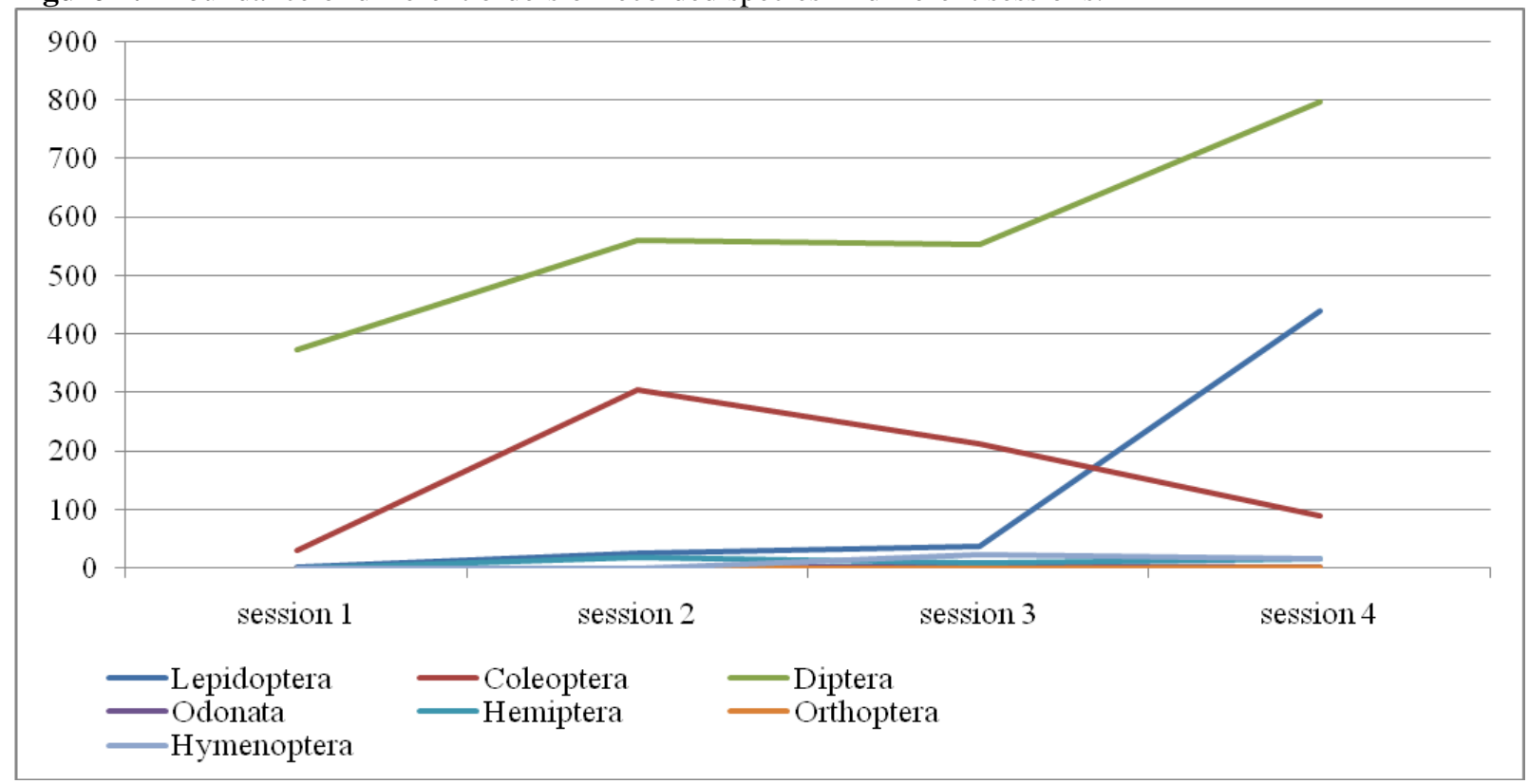

During this present study, it has been observed that, the number of occurrence of Altica sp. (Coleoptera) was found to be increased with the increase of the number of Amata passalis (Fabricius, 1781) and Amata cyssea Stoll, 1782 (Lepidoptera). Similarly the number of occurrence of Lipaphis erysimi Kaltenbach, 1843 (Hemiptera) was found to be increased with the increase of the number of Plutella sp. (Lepidoptera). Increased number of Eurema hecabe (Linnaeus, 1758) (Lepidoptera) was coupled with the increased number of occurrence of Coccinella septempunctata (Linnaeus, 1758) (Coleoptera). There was no data had been recorded to comment on the correlation of the occurrences of species-pairs. But the personal observation state that the abundance (by numbers) of Plutella sp. had been increased when the numbers of Amata passalis (Fabricius, 1781) and Amata cyssea Stoll, 1782 had decreased. Similarly, the number of Altica sp. had been higher when the number of Plutella sp. was less.

\section{Discussion:-}

Most of the species in the present study had been recorded within a pre-determined time schedule. There was no study of visitation frequency or duration of stay or amount of pollen carried by the insect individuals had been conducted. The species which were mentioned as pollinators or effective pollinators were stated purely on the basis of earlier references (Sung et al., 2006; Chen et al., 2015; Sajjad et al., 2015; Roy and Mitra, 2012).

The species which were observed in the different parts of plant individuals probably denoted their nature of interaction with the nectar plants (Thakur and Mattu, 2014; Hayter and Cresswell, 2006). Species which were mostly found on flowers most of them were pollinators, however, pollinator species might be found on other parts of plants like leaf, stem etc. In other words, pollinator species have specific intension for nectar and also target locations like flowers (Westphal et al., 2003; Rajkumar et al., 2015; Bhuyan et al. 2005). But some species which are casual visitors or occasional pollinators can be found different locations of nectar plants even excluding flowers as they don't have such intensions (Sima et al., 2014; Rajkumari et al., 2014).

The efficiency of pollination of certain species can be affected by the presences of other species (Meena et al., 2015; Mahmoud and Shebl, 2014; Navatha and Sreedevi, 2012). During this study, it has been observed that the number and presence of specific insect species/group is responsible for presence or abundance of other insect species/group. For examples, in between Altica sp. (Coleoptera) and Amata passalis (Fabricius, 1781) and Amata cyssea Stoll, 1782 (Lepidoptera), Lipaphis erysimi Kaltenbach,1843 (Hemiptera) and Plutella sp. (Lepidoptera) and Eurema hecabe (Linnaeus, 1758) (Lepidoptera) and Coccinella septempunctata (Linnaeus, 1758) (Coleoptera).

The presence of more than one species depending on same resources sometime shows the symbiotic interaction between species or order pairs (Abid et al., 2010; Dharmendra et al., 2014). This symbiotic interaction might be 
positive or negative, as the presence or absence of any order or species may allow or restrict some other order (Kapkoti et al., 2016; Revathi and Remadevi, 2011). In the present study, the session-wise abundance of order Diptera has negatively related with the order Coleoptera and positively related with the order Hemiptera.

The overall study showed the species abundance of different orders in the blooming stage of Brassica juncea $\mathrm{L}$. Of them, Lepidoptera had maximum number of species occurrence followed by Coleoptera and Hymenoptera. The blooming period of Brassica juncea $\mathrm{L}$. varies from 20 days to 22 days depending on many environmental factors (Roy et al., 2014). This study also revealed that, most of the insect species start to visit at its full grown time and reduces their occurrence gradually. Similarly, many species occur at the post blooming phase (after 8 to 9 days of blooming) and stay still they are dried up. There are also some species which were found irregularly throughout the blooming session and there was no specific interaction with other co-taxa.

In the present study, there was no species which was collected exclusively from stem or leave. The species which was collected from stem and leaves was mostly local inhabitants and frequently available. Many species were found in different plant parts but most of them had a common location with flowers. It clearly indicates that most of the insect species has specific intension of nectar collection which led the pollination efficiency. Present study also focused that presence of other non-specific insect groups may also act as indicator of specific pollinator groups and their symbiotic interaction may cause the effective pollination of that particular crops.

\section{Acknowledgement:-}

Authors are acknowledged to Dr. Kailash Chandra, Director, Zoological Survey of India for giving necessary permissions for this work. Thanks are also due to Shri K. C. Gopi, Additional Director and in-charge of Entomology Division, Zoological Survey of India for constant support and help. Authors are gratefully acknowledged to Shri Subham Paul for his support in the field.

\section{References:-}

1. Abid, R., Alam, J. and Qaiser, M. (2010): Pollination Mechanism and Role of Insects in Abutilon indicum (L.) Sweet. Pak. J. Bot., 42(3): 1395-1399.

2. Alagumurugan, C., Pavaraj, M. and Rajan, M.K. (2011): Seasonal and relative abundance of butterflies in a scrub jungle habitat of Peraiyur Taluk, Madurai District, Tamilnadu. Journal of research in Biology, 1: 44-50.

3. Ali, H., Owayss, A.A., Khan, K.A. and Alqarni, A.S. (2015): Insect Visitors and Abundance of Four Species of Apis on Sunflower Helianthus annuus L. in Pakistan. Acta zool. bulg., 67 (2): 235-240.

4. Atmowidi, T., Buchori, D., Manuwoto, S.,Suryobroto, B. and Hidayat, P. (2007): Diversity of Pollinator Insects in Relation to Seed Set of Mustard (Brassica rapa L.: Cruciferae). Journal of Biosciences, 14(4): 155161.

5. Belavadi, V.V. and Ganeshaiah, K.N. (2013): Insect Pollination Manual. Department of Agricultural Entomology. University of agricultural Science, Bangalore.

6. Bhalchandra, W., Baviskar, R.K. and Nikam, T.B. (2014): Diversity of nectariferous and polleniferous bee flora at Anjaneri and Dugarwadi hills of Western Ghats of Nasik district (M. S.) India. Journal of Entomology and Zoology Studies, 2 (4): 244-249.

7. Bhuyan, M., Kataki, D., Deka, M. and Bhattacharya, P.R. (2005): Nectar host plant selection and floral probing by the Indian butterfly Danaus genutia (Nymphalidae). Journal of Research on the Lepidoptera, 38: 79-84.

8. Chen, G., Jürgens, A., Shao, L., Liu, Y., Sun, W. and Xia C. (2015): Semen-Like Floral Scents and Pollination Biology of a Sapromyophilous Plant Stemona japonica (Stemonaceae). Journal of Chemical Ecology, 41:244252. DOI 10.1007/s10886-015-0563-0.

9. Dharmendra, K., Raju, S.V.S. and Nagrajan, C. (2014): Occurrence of insect-pests and their natural enemies' on cauliflower Brassica oleracea var. Botrytis in Varanasi. Bioinfolet, 11(2a): 323-325.

10. Duara, P. and Kalita, J. (2013): An Investigation on the Pollinating Insects of Medicinally Important Plants. International Journal of Life Science Biotechnology and Pharma Research, 2(1): 318-324.

11. Goswami, V. and Khan, M.S. (2014): Impact of Honey Bee Pollination on Pod Set of Mustard (Brassica Juncea L.: Cruciferae) At Pantnagar. The Bioscan, 9(1): 75-78.

12. Hayter, K.E. and Cresswell, J.E. (2006): The influence of pollinator abundance on the dynamics and efficiency of pollination in agricultural Brassica napus: implications for landscape-scale gene dispersal. Journal of Applied Ecology, 43: 1196-1202. 
13. Hossain, M. (2014): Check list of butterflies of the Sundarbans mangrove forest, Bangladesh. Journal of Entomology and Zoology Studies, 2 (1): 29-32.

14. Hu, M.Y., Zhong, G.H., Sun, Z.T., Sh, G., Liu, H.M. and Liu, X.Q. (2005): Insecticidal activities of secondary metabolites of endophytic Pencillium sp. in Derris elliptica Benth. Journal of Applied Entomology, 129(8): 413-417.

15. Kapkoti, B., Joshi, R.K. and Rawal, R.S. (2016): Variations in the abundance and diversity of insects in apple orchards of Kumaun, Western Himalaya, India. Current Science, 110(3): 438-443.

16. Kulloli, S.K., Chandore, A.N. and Aitawade, M.M. (2011): Nectar dynamics and pollination studies in three species of Lamiaceae. Current Science, 100(4): 509-516.

17. Kunjwal, N., Kumar, Y. and Khan, M.S. (2014): Flower-visiting insect pollinators of Brown Mustard, Brassica juncea (L.) Czern and Coss and their foraging behavior under caged and open pollination. African Journal of Agricultural Research, 9(16): 1278-1286.

18. Mahmoud, M.F., Shebl, M. (2014): Insect fauna of canola and phenology of the diamondback moth, Plutella xylostella L. (Lepidoptera Plutellidae) as a key pest. REDIA, XCVII: 125-132.

19. Meena, N.K., Singh, B., Kant, K., Meena, R.D. and Solanki, R.K. (2015): Role of insect pollinators in pollination of seed spices-A review. International J. Seed Spices, 5(1): 1-17.

20. Mitra, B. (2010): Diversity of Flower Visiting Flies (Insecta: Diptera) In India and Their Role in Pollination. Rec. zool. Surv. India, 110 (Part-2): 95-107.

21. Mitra, B., Parui, P., Banerjee, D., Mukherjee, M. and Bhattacharjee, K. (2005): A Report On Flies (Diptera: Insecta) as Flower Visitors and Pollinators of Kolkata and it's Adjoining Areas. Rec. zool. Surv. India, 105 (Part-3-4):1-20.

22. Navatha, L. and Sreedevi, K. (2012): Insect pollinator diversity and abundance in Castor, Ricinus communis L. Current Biotica, 6(2): 251-253.

23. Navatha, L., Sreedevi, K., Chaitanya, T., Prasad, P.R. and Naidu, M.V.S. (2012): Species richness and foraging activity of insect visitors in linseed (Linum usitatissimum L.). Current Biotica, 5(4): 465-471.

24. Nicholls, C.I. and Altieri, M.A. (2013): Plant biodiversity enhances bees and other insect pollinators in agroecosystems. A review. Agron. Sustain. Dev., 33(2): 257-274. DOI 10.1007/s13593-012-0092-y.

25. Raghavan, R. and Dahanukar, N. (2015): Taxonomy matters. Current Science, 108(8): 1416-1418.

26. Rajkumar, K., Keshavanarayan, P. and Sivaram, V.(2015): Pollination Biology and Breeding System of Eugenia discifera Gamble- an Endangered Species of Western Ghats, India. International Journal of Science and Nature, 6(1): 1-11.

27. Rajkumari, P., Sharmah, D., Rahman, A. and Patgiri, P. (2014): Diversity and Distribution Pattern of Hymenopteran Insects in Jorhat District, Assam, India. International Journal of Science and Research, 3(12): 1938-1941.

28. Rasheed, M.T., Inayatullah, M., Shah, B., Ahmed, N., Huma, Z. and Ahmed, S. (2015): Identification and record of insect pollinators on two cultivars of sunflower. Journal of Entomology and Zoology Studies, 3(6): 178-179.

29. Revathi, T.G. and Remadevi, O.K. (2011): Review on beneficial insects and report on ants occurring on cultivated bamboos in India. Current Biotica, 5(1): 107-120.

30. Roy, K. and Mitra, B. (2012): Evaluating Pollinator Effectiveness on Tagetes patula Linnaeus. Rec. zool. Surv. India, 112 (Part-2): 71-74.

31. Roy, S., Gayen, A.K., Mitra, B. and Duttagupta, A. (2014): Diversity, foraging activities of the insect visitors of Mustard (Brassica juncea Linnaeus) and their role in pollination in West Bengal. The Journal of Zoology Studies, 1(2): 07-12.

32. Sajjad, A., Saeed, S. and Masood, A. (2008): Pollinator Community of Onion (Allium cepa L.) and its Role in Crop Reproductive Success. Pakistan J. Zool., vol. 40(6): 451-456.

33. Sima.,Bhati, D., Srivastava, M. (2014): Floral Visitors of Different Crops as Recorded from an Agro-Ecosystem near Jhunjhunu, Rajasthan (India). International Journal of Science and Research, 3(9): 1732-1738.

34. Sung, I.H., Lin, M.Y., Chang, C.H., Cheng, A.S., Chen, W.S. and Ho, K.K. (2006): Pollinators and Their Behaviors on Mango Flowers in Southern Taiwan. Formosan Entomol., 26: 161-170.

35. Thakur, B. and Mattu, V.K. (2014): Diversity and distribution of pollinators of temperate fruit crops of Shimla hills in Himachal Pradesh. Asian J. of Adv. Basic Sci., 3(1): 151-163.

36. Tiple, A.D., Khurad, A.M. and Dennis, R.L.H. (2007): Butterfly diversity in relation to a human-impact gradient on an Indian university campus. Nota lepid., 30 (1): 179-188.

37. Westphal, C., Dewenter, I.S. and Tscharntke, T. (2003): Mass flowering crops enhance pollinator densities at a landscape scale. Ecology Letters, 6: 961-965. 